\title{
Information Sharing and Supply Chain Collaboration: Strategy for Higher Firm Performance in Ghana
}

\author{
Vanessa Fathia Baba* ${ }^{(0)}$, Tianri Wang, Sophia Akosua Adzani, Zalia Abdul-Hamid \\ College of Economics and Management, Taiyuan University of Technology, Taiyuan, China \\ Email: *vanessafathia@gmail.com, wangtianri@tyut.edu.cn, sophiaadzani@ymail.com, zaliaabdulhamid96@gmail.com
}

How to cite this paper: Baba, V. F., Wang, T., Adzani, S. A., \& Abdul-Hamid, Z. (2021). Information Sharing and Supply Chain Collaboration: Strategy for Higher Firm Performance in Ghana. American Journal of Industrial and Business Management, 11, 635-645.

https://doi.org/10.4236/ajibm.2021.116041

Received: May 7, 2021

Accepted: June 8, 2021

Published: June 11, 2021

Copyright $\odot 2021$ by author(s) and Scientific Research Publishing Inc. This work is licensed under the Creative Commons Attribution International License (CC BY 4.0).

http://creativecommons.org/licenses/by/4.0/

(c) (i) Open Access

\begin{abstract}
Information sharing (IS) has been considered a vital aspect of supply chain management practices. However, it is inadequate to induce a significant increment in performance, so there is a need for collaboration within the supply chain network arises. This study seeks to determine the position of Information Sharing (IS) practices and Supply Chain Collaboration (SCC) in Firm Performance (FP). The study emphasizes that firms exchange information because of the competitive influence stemming from the business environment. The study administered questionnaires to manufacturing firms in Ghana with 201 respondents, and the structural equation modeling tested the relationship between IS, SCC, and FP. The results indicate that firms with higher levels of IS and SCC witness high-performance rates. Also, supply chain collaboration can have a direct, positive influence on the performance of firms. The study is limited in scope, which lessens the generalization of the results. This study is unique because it simultaneously examines the role of information sharing on both collaboration and firm performance.
\end{abstract}

\section{Keywords}

Information Sharing, Supply Chain Collaboration, Supply Chain Networks, Firm Performance, Structural Equation Modeling

\section{Introduction}

Over the years, the essence of competition has evolved to the degree that firms no longer compete against other firms based on quality as traditionally practiced. Nonetheless, the current competition source lies outside the firm's walls, inspired by how effectively firms connect their operations with their supply 
chain network. Forging market relationships with suppliers, customers, and other strategic partnerships anchored on trust and commitment becomes a crucial competing parameter.

Consequently, a firm's supply chain network has become a necessary agenda accelerating decision-making at the top-level management. Every supply chain practice aims to minimize costs while satisfying customer service level demands. Ideally, in a typical supply chain system, suppliers and customers are conjoined into one collective business process that traverses the entire chain from the primary source to the final consumer (Nazifa \& Ramachandran, 2019). It implies that every single firm depends on other firms to deliver its goods or services to customers (Seggie et al., 2006). It is evident firms benefit from the practice of information sharing. The study investigates the connection between information sharing and collaborations within the supply chain networks on firm performance.

Specifically to ascertain,

To identify the role of information sharing on collaboration practices.

To ascertain the connection between information sharing and the performance of a firm.

To discover the impact supply chain collaboration has on firm performance.

\section{The Proposed Research Framework}

The framework asserts a relationship between information sharing, collaboration, and firm performance. The research framework classifies the various variables that forecast information sharing including, the level and quality of information sharing. It declares that collaboration practice served as the mediator for information sharing and higher firm performance. The subsections illustrate the variables in the framework, accompanied by the research hypothesis (Figure 1).

The subsequent Section "2" will cover the literature relating to the research objectives and the research hypothesis. The third section highlights the research design and methodology. The fourth part gives details on the data analysis comprising; the data reduction, measurement of reliability and validation, and the results of the proposed model. The fifth and sixth section discusses findings, conclusions, the general implications, and further research.

\section{Literature Review}

\subsection{Information Sharing}

Information sharing (IS) is essential in the supply chain system both theoretically and practically because it helps improve firm performance. However, ascertaining its benefits can only be through collaboration with other supply chain partners. The underlying notion is that a firm cannot compete on its own but needs to collaborate with other parties (Min et al., 2016).

\section{Information sharing level}

Information sharing consists of two dimensions; the level and the quality of 
information shared. These two aspects are vital for SCM practice and, past studies have tackled these dimensions as independent constructs (Moberg et al., 2002). The level is how critical and exclusive information is transferred to various partners.

Various researches suggest that the solution to a successful supply chain system is; making available accurate and latest business data at every link of the supply chain. However, ensuring the availability of data and sharing it with supply chain members can serve as a source of improving firm performance (Kim et al., 2006). Sundram et al. (2018) acknowledges information sharing as one of the five practices that define a dependable supply chain relationship. According to Pamulety and Pillai (2011), partners who regularly share information have the capability of working as a single entity. As an entity, it aids in better recognizing the requirements of the customer. Therefore, there is a quicker response to market change.

\section{Quality of information sharing}

Although information sharing is essential, the consequence of its influence on FP depends on what, when, how, and with whom the information is shared ( $\mathrm{Li} \&$ Lin, 2006).

Research suggests that firms intentionally diminish information that can probably get to their competitors and even their supply chain partners. It seems that there is an automatic hesitancy within firms to reveal a significant amount of information since disclosure is considered a lack of control on the part of firms (Li \& Lin, 2006). As a result, the information sharing quality becomes a vital aspect of SCC and FP.

\subsection{Collaboration}

The fundamental notion is that a firm cannot compete by itself. The firm needs to collaborate with other parties (Min et al., 2016). Supply chain Collaboration is considered one of the essential abilities that a firm needs to remain in a stable business environment. According to Simatupang and Sridharan (2002), collaboration within the supply chain refers to independent firms working together to plan and perform supply chain activities whiles achieving higher progress than when working alone. Vickery et al. (2003) acknowledges that collaboration involves partnering with suppliers to ensure effective customer relations. The partnership involves suppliers in product development and decision-making through accessing technological capacities (Simatupang \& Sridharan, 2002; Droge et al., 2004). This partnership must ensure that there is supplier satisfaction at all times.

Wilkinson (1981) found that non-coercive power boosts satisfaction with other channel members. Baihaqi and Sohal (2012) found that supply chain collaboration mediates the relationship between IS and FP.

\subsection{Firm Performance}

Firm performance assessment is not only based on capabilities and outcomes but 
also from a competitive market perspective. The measures for performance comprise: return on asset, market share, return on investment, net profit, growth in net profit, sales, gross margin, quality performance, productivity ratio, inventory, market performance, financial liquidity, etc. and other non-financial measures such as the present value of the firm, market share, and innovation performance.

The FP in this study is measured using indicators such as profit, sales, and market share Findings from (Barney, 2016) concluded that Information Sharing resources, such as applied technological and administrative innovations, enhance internal capabilities, and influence firm performance. Again, most studies agree that the basis of information sharing is trust between supply chain partners.

\subsection{Research Hypotheses}

The IS framework generated in this study suggests; information sharing has a positive effect on supply chain performance and the overall firm performance. Information sharing is presumed to improve supply chain collaboration, a firm's market share, and returns.

The variables were analyzed using the AMOS 7 structural equation model (SEM) to support the hypothesis and determine the significance of the hypothesized construct. Based on the reviewed literature, the study hypothesis includes:

Hypothesis 1. Information sharing has a positive impact on supply chain collaboration.

Hypothesis 2. Firms with greater levels of information sharing observe an increase in performance.

Hypothesis 3 . The higher the supply chain collaboration, the higher the firm performance.

Hypothesis 4: Collaboration mediates the relationship between information sharing and firm performance.

The above hypotheses form the basis of the framework presented in Figure 2.

\section{Research Methodology}

Statistical analysis determined the reliability and validity of the information sharing, supply chain collaboration, and firm performance instruments. The descriptive statistics employed the Statistical Package for Social Sciences (SPSS) to analyze the data obtained. Also, a data reduction method was applied to break down the measurement items into corresponding simplified forms. The secondary data in the study is obtained from an extensive literature review of supply chain sustainability.

\subsection{Data Collection}

The study obtained data through mail and Internet surveys that targeted top and lower-level management. The study deployed the random sampling technique 
with a population of 655 organizations; 201 respondents were selected randomly to administer the questionnaire. The sample size was determined using (Yamane, 1967) formulae represented below.

$$
n=\frac{N}{1+N(\alpha)^{2}}
$$

Given that:

- The desired sample size represented by $n$;

- The margin of errors (0.05) at $95 \%$ level of confidence is represented by " $\alpha$ ";

- The constant figure is " 1 ";

- The total population is represented by " $N$ ".

$$
\begin{aligned}
& n=\frac{655}{1+655(0.0025)} \\
& n=\frac{500}{1+2.25} \\
& n=\frac{655}{3.25} \\
& n=201.538
\end{aligned}
$$

\begin{tabular}{|c|c|c|c|}
\hline Variable & Category & Frequency & Percentage \\
\hline \multirow[t]{2}{*}{ Gender } & Male & 80 & 39.8 \\
\hline & Female & 121 & 60.2 \\
\hline \multirow[t]{5}{*}{ Age } & $20-25$ & 2 & 1.0 \\
\hline & $26-30$ & 14 & 7.0 \\
\hline & $31-35$ & 103 & 51.2 \\
\hline & $36-40$ & 76 & 37.8 \\
\hline & 41 and above & 6 & 3.0 \\
\hline \multirow[t]{3}{*}{ Academic qualification } & Bachelor & 56 & 27.9 \\
\hline & Masters' & 137 & 68.2 \\
\hline & $\mathrm{PhD}$ & 8 & 4.0 \\
\hline \multirow[t]{4}{*}{ Job title } & $\mathrm{CEO} /$ President/Vice president & 16 & 8.0 \\
\hline & Director & 35 & 17.4 \\
\hline & Manager & 141 & 70.1 \\
\hline & Other & 9 & 4.5 \\
\hline \multirow[t]{4}{*}{ Number of employees } & $100-250$ & 53 & 26.4 \\
\hline & $251-500$ & 146 & 72.6 \\
\hline & $501-1000$ & 1 & 0.5 \\
\hline & 1000 and above & 1 & 0.5 \\
\hline
\end{tabular}

Additionally, the demographics of respondents were representative satisfactory, depicted in Table 1.

Table 1. Characteristics of respondent.

${ }^{\star} n=201$. 


\subsection{Measurements}

After critical observation, the Likert scale was considered the suitable scale for this study. All scale items which evaluate variables were generated based on those attained from existing research. The Likert scale by Rensis Likert is appropriate on account of its simplicity and convenience. The study calculated variables on a seven-point Likert scale from 1 (very-disagree) to 7 (very agree).

\section{Reliability and Validity Assessment}

The study conducted a data reduction process aimed at collapsing all measurement items. The analysis subjected various constructs to reliability and before the calculation of the composite score. The Kaiser-Meyer-Olkin measure of sampling adequacy (Kaiser, 1974) and the Barlett test of sphericity (Bartlett, 1954) established principal component results reliability and reliability of IS, SCC, and FP assessed employing Cronbach's Alpha.

The convergent validity of the measurement constructs was estimated employing the confirmatory factor analysis. The study performed a factor analysis on IS, SCC, and FP using the five, four, and three items. The composite measure of each construct in their various mean values, standard deviations, and correlations calculated, shown in Table 2 (Bobko et al., 2007). The reliability values and the factor loadings in Table 2 for all constructs were higher than 0.70 , average variance extracted (AVE) was greater than 0.5 as shown in Figure 2, indicating a satisfactory convergent and discriminant validity.

\section{Descriptive Statistics}

According to Pallant (2020), the correlation results should be within the range of 0.3 to 0.7 . However, it must not be too high or too low. The results of the assessment of correlations variables were within 0.4 to 0.8 . There is a positive correlation between the variables with all of the values above 0.3 shown in Table 1 .

Table 2, means, standard deviations, and correlations (a) information sharing, (b) supply chain collaboration, (c) firm performance

\section{Analysis of the Structural Model and Hypotheses Testing}

The variables in Figure 1 were analyzed applying the AMOS 7 structural equation model (SEM). The composite factor analysis results revealed a good fit between the model and data $\left(\chi \chi^{2}=221.733 d f=197\right)$, Root Mean Square Error of Approximation $[$ RMSEA] $=0.026$, Comparative Fit Index $(\mathrm{CFI})=0.990$, and Normed Fit Index $(\mathrm{NFI})=0.915)$. The hypothesized construct was analyzed significantly as predictable, and the conclusions construct validity was satisfactory.

Additionally, the correlations between the various constructs were significantly different from (Bagozzi et al., 1991). The final structural model represented in Figure 2 achieved a good fit shown by the fit measures. Therefore, the final model shown in Figure 2 supported the hypotheses of this study. The summary of hypothesis testing is defined below. 
Table 2. (a) Means, standard deviations, correlations, factor loadings, and reliability for information sharing; (b) Means, standard deviations, correlations, factor loadings and reliability for supply chain collaboration; (c) Means, standard deviations, correlations, factor loadings and reliability for supply chain collaboration.

(a)

\begin{tabular}{lccccccccc}
\hline \multicolumn{1}{c}{ Item description } & Item code & Mean & SD & $\mathbf{1}$ & $\mathbf{2}$ & $\mathbf{3}$ & $\mathbf{4}$ & $\mathbf{5}$ & Factor loading \\
\hline Information sharing & & & & & & & & & 0.81 \\
Share changing needs & IS1 & 4.65 & 0.69 & 1 & & & & & 0.83 \\
Share issues affecting the firm & IS2 & 4.31 & 0.71 & $0.55^{* *}$ & 1 & & & & 0.90 \\
Share proprietary information & IS3 & 4.27 & 0.74 & $0.58^{* *}$ & $0.76^{* *}$ & 1 & & 0.92 \\
Timely information & IS4 & 4.34 & 0.75 & $0.47^{* *}$ & $0.59^{* *}$ & $0.63^{* *}$ & 1 & & 0.78 \\
Accurate information & IS5 & 4.39 & 0.73 & $0.63^{* *}$ & $0.56^{* *}$ & $0.57^{* *}$ & $0.63^{* *}$ & 1 & 0.76 \\
\hline
\end{tabular}

(b)

\begin{tabular}{|c|c|c|c|c|c|c|c|c|c|}
\hline Item description & $\begin{array}{l}\text { Item } \\
\text { code }\end{array}$ & Mean & SD & 1 & 2 & 3 & 4 & $\begin{array}{c}\text { Factor } \\
\text { loading }\end{array}$ & Reliability \\
\hline \multicolumn{10}{|l|}{ Supply chain collaboration } \\
\hline Frequent contact & SCC1 & 4.67 & 0.68 & 1 & & & & 0.82 & \\
\hline Compatible communication and information systems & SCC2 & 4.35 & 0.72 & $0.66^{* *}$ & 1 & & & 0.74 & 0.91 \\
\hline Supply chain beyond customers and suppliers & SCC3 & 4.38 & 0.72 & $0.61^{\star *}$ & $0.67^{\star *}$ & 1 & & 0.79 & \\
\hline Participation in marketing efforts of customers & SCC4 & 4.45 & 0.70 & $0.60^{\star *}$ & $0.64^{* *}$ & 0.75 & 1 & 0.73 & \\
\hline
\end{tabular}

(c)

\begin{tabular}{lccccccc}
\hline \multicolumn{1}{c}{ Item description } & Item code & Mean & SD & $\mathbf{1}$ & $\mathbf{2}$ & $\mathbf{3}$ & Factor loading Reliability \\
\hline Firm performance & & & & & & & 0.87 \\
Return on sale & FP1 & 4.12 & 0.63 & 1 & & 0.75 & 0.84 \\
Return on assets & FP2 & 4.13 & 0.73 & $0.68^{* *}$ & 1 & & 0.78 \\
Market share & FP3 & 4.18 & 0.68 & $0.64^{* *}$ & $0.63^{* *}$ & 1 & \\
\hline
\end{tabular}

${ }^{* *}$ Correlation is significant at the 0.01 level (two-tailed). ${ }^{*}$ for all measures, 7 -point Likert-type scales were used $(1=$ strongly disagree, $7=$ strongly agree).

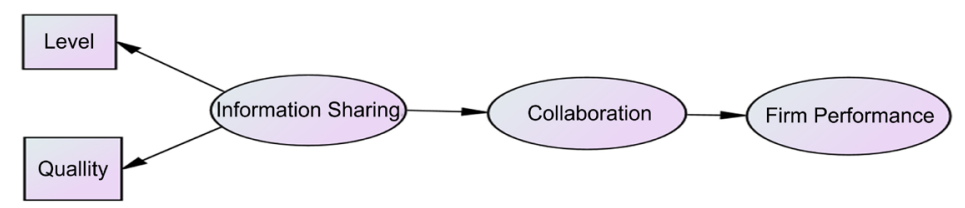

Figure 1. A conceptual framework of IS, SCC, and FP.

Hypothesis 1: Information sharing has a positive impact on supply chain collaboration. The analysis supported the research hypothesis (standardized coefficient $0.95 ; p<0.05)$. The results indicate that close-collaborations within the supply chain network necessitate a greater level of information sharing.

Hypothesis 2. Firms with greater levels of information sharing observe an increase in performance. The analysis supported the research hypothesis (standardized coefficient $0.70 ; p<0.05$ ).

Hypothesis 3: The firms with higher supply chain collaboration achieve higher performance. The analysis supported the research hypothesis (standardized coefficient $0.30 ; p<0.05$ ). The findings support the assertion that supply chain collaboration or integration has a direct influence on Firm performance.

Hypothesis 4: Collaboration directly mediates the relationship between information sharing and firm performance. This hypothesis is supported (standardized coefficient $0.31 ; p<0.05)$. 


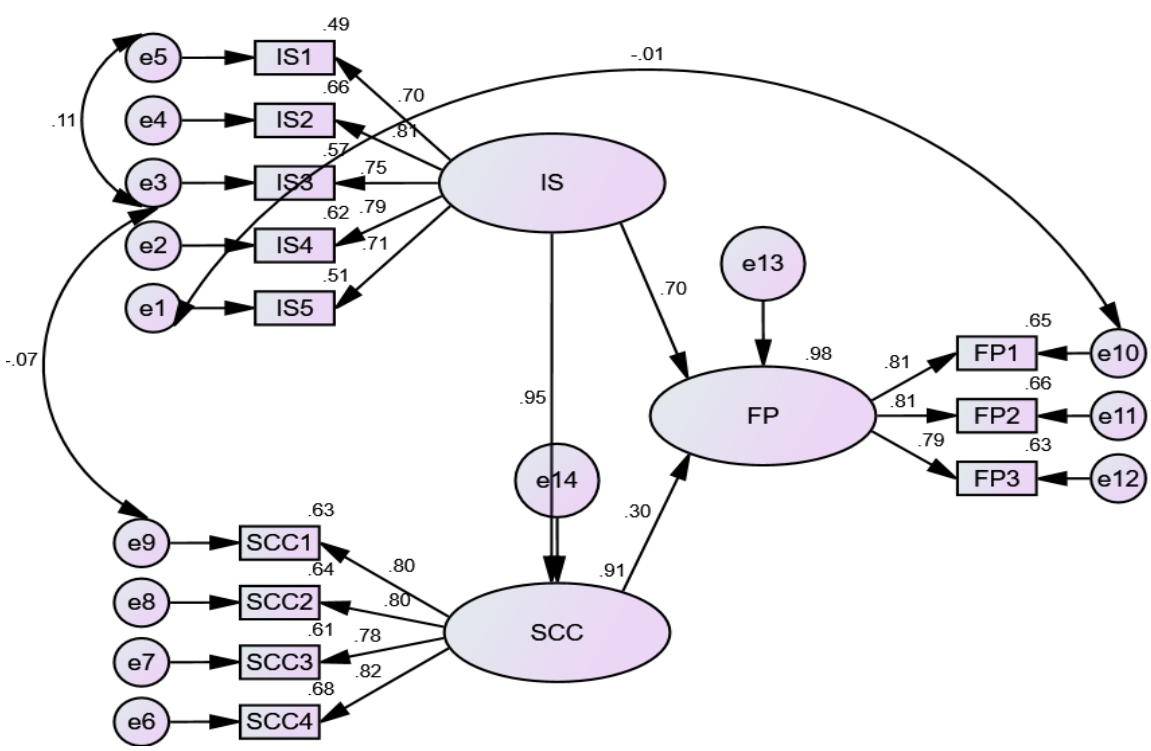

Figure 2. Final model of Information sharing (IS), supply chain collaboration (SCC), and firm performance (FP).

Table 3. Hypothesis testing results.

\begin{tabular}{ccccccc}
\hline Hypothesis & Relationship & Path coefficient & SE & t-value & $p$-value & $\begin{array}{c}\text { Hypothesis } \\
\text { Decision }\end{array}$ \\
\hline H1 & IS $\rightarrow$ SCC & 0.954 & 0.099 & 1.456 & $* * *$ & Supported \\
H2 & IS $\rightarrow$ FP & 0.698 & 0.293 & 11.792 & 0.025 & Supported \\
H3 & SCC $\rightarrow$ FP & 0.300 & 0.262 & 3.455 & 0.326 & Supported \\
& & Bootstrap Analysis of Indirect Effect of IS & \\
& & Estimate & SE & LLCI & ULCI & \\
H4 & $($ IS*SCC $\rightarrow$ FP & 0.309 & 0.049 & 0.227 & 0.495 & Supported \\
\hline
\end{tabular}

The results displayed in Table 3 support the hypothesis (Hypothesis 1, Hypothesis 2, Hypothesis 3, and Hypothesis 4) of this study. The relationship between Information Sharing (IS) and Supply Chain Collaboration (SCC) obtained a path coefficient of 0.954 , proving that the relationship between IS and SCC is positively significant. This result supports the hypothesis of the study.

Also, the path coefficient of Information Sharing (IS) and Firm Performance (FP) was 0.698 , showing a significant relationship between IS and FP.

Again, the result of the relationship between Supply Chain Collaboration (SCC) and Firm Performance (FP) supported the research hypothesis (path coefficient $=0.300$ ). Furthermore, the bootstrap analysis of the indirect effect of Information Sharing (IS) supported the research hypotheses that collaboration directly mediates the relationship between IS and FP (path coefficient $=0.309$ ). The Lower Level Confidence Interval (LLCI) and Upper Level Confidence Interval (ULCI) were significant, with LLCI recording a value of 0.227 and ULCI recorded 0.495 (95\% confidence level). The results are in line with Baihaqi and Sohal (2012) 
conclusion that supply chain collaboration mediates the relationship between IS and FP.

\section{Implications and Limitations}

Notable implications unveiled from the outcome of this study translate into a series of recommendations. These recommendations may benefit firms in the supply chain management field. This study shows the magnitude of how information sharing between supply chain partners affects firms. The research contributes to knowing the professional performances of information flow within the supply chain network.

In recent times, top-level management does not only tackle performance improvement within their firms but also beyond their supply chain network. The study presents two vital outlooks toward effective IS practices; supply chain collaboration leading to firm performance improvement.

Firstly, it demonstrates that Information Sharing is the main driver for firms to ensure higher collaboration across the supply chain network. Additionally, information flow through supply chain collaborations stimulates the movement of relevant information, supporting supply chain performance which eventually helps in firm performance.

Based on these arguments, it is evident that firms need to invest in sharing propriety information through IT systems to develop their organizational capacities and better help both the upstream and downstream.

Lastly, organizations need to employ adaptive information-sharing practices to attain the desired level of firm performance. Therefore, competition is not among firms but supply chain partners. The findings guarantee that information sharing can be an effective way for firms to be competitive and ultimately improve firm performance. The investigation adds to the existing literature on IS, SCC, and FP.

A limitation stems from the data collected. The data was solely from Ghana, which lessens the generalization of the results to other countries because countries have varying characteristics and geographical features. The geographical limitation in a Ghanaian setting is a constraint because the data were obtained solely from the firms in the industrial areas of Accra, Kumasi, and Nsawam.

\section{Conclusion and Further Research}

Finally, the study results can be a facilitator for management in the supply chain sector to appreciate the significance of the connection between IS, SCC, and FP measures. An in-depth literature review captured the general research question and synthesized the relationship between IS, SCC, and FP. The outcomes show that implementation of IS, SCC is significantly connected with FP. These findings were in conformance with the study by Baihaqi and Sohal (2012) and Sundram et al. (2020).

This study further reveals that supply chain collaboration has a significant ef- 
fect on firm performance. The results of the research are crucial for firms' performance improvement in Ghana. Since the study results show that there is indeed a relationship between IS, SCC, and FP, and it should be adopted by firms when implementing strategies for the firm to maintain its presence in a competitive environment across the supply chain network. The result can be an informative model for decision-makers across supply chain networks for decisionmaking processes. Overall, the research enriches the existing research through the different outlooks presented on the relationships between IS practices, SCC, and firm performance. The study used only the level and quality of IS as the dimension for supply chain collaboration in organizations.

Further study can investigate whether other dimensions also have effects on SCC. Also, additional research should explore whether information communication technology (ICT) affects "IS" flow in Ghana, where most firms have not fully adopted ICT as a means of information sharing within the supply chain network. This exploration will heighten the validity and parameters of the study. The constructs and proposed model can be a foundation for further research that tests information sharing, supply chain collaboration, and firm performance. Further studies should concentrate on other regions of Ghana to discern the generalizability of this study's findings.

\section{Acknowledgements}

We acknowledge the support team in Ghana for their assistance in the data collection of this study.

\section{Conflicts of Interest}

The authors declare no conflicts of interest regarding the publication of this paper.

\section{References}

Bagozzi, R. P., Yi, Y., \& Phillips, L. W. (1991). Assessing Construct Validity in Organizational Research. Administrative Science Quarterly, 36, 421-458. https://doi.org/10.2307/2393203

Baihaqi, I., \& Sohal, A. S. (2012). The Impact of Information Sharing in Supply Chains on Organisational Performance: An Empirical Study. Production Planning \& Control, 24, 743-758. https://doi.org/10.1080/09537287.2012.666865

Barney, J. (2016). Firm Resources and Sustained Competitive Advantage. Journal of Management, 17, 99-120. https://doi.org/10.1177/014920639101700108

Bartlett, M. S. (1954). A Note on the Multiplying Factors for Various Chi-Square Approximations. Journal of the Royal Statistical Society, Series B (Methodological), 16, 296-298. https://doi.org/10.1111/j.2517-6161.1954.tb00174.x

Bobko, P., Roth, P. L., \& Buster, M. A. (2007). The Usefulness of Unit Weights in Creating Composite Scores: A Literature Review, Application to Content Validity, and Meta-Analysis. Organizational Research Methods, 10, 689-709.

https://doi.org/10.1177/1094428106294734

Droge, C., Jayaram, J., \& Vickery, S. K. (2004). The Effects of Internal versus External Integration Practices on Time-Based Performance and Overall Firm Performance. Journal of Operations Management, 22, 557-573. https://doi.org/10.1016/j.jom.2004.08.001 
Kaiser, H. F. (1974). An Index of Factorial Simplicity. Psychometrika, 39, 31-36. https://doi.org/10.1007/BF02291575

Kim, D., Cavusgil, S. T., \& Calantone, R. J. (2006). Information System Innovations and Supply Chain Management: Channel Relationships and Firm Performance. Journal of the Academy of Marketing Science, 34, Article No. 40. https://doi.org/10.1177/0092070305281619

Li, S., \& Lin, B. (2006). Accessing Information Sharing and Information Quality in Supply Chain Management. Decision Support Systems, 42, 1641-1656. https://doi.org/10.1016/j.dss.2006.02.011

Min, H. J., Joo, S.-J., \& Nicolas-Rocca, T. S. (2016). Information System Outsourcing and Its Impact on Supply Chain Performances. International Journal of Logistics Systems and Management, 24. https://doi.org/10.1504/IJLSM.2016.077280

Moberg, C. R., Cutler, B. D., Gross, A., \& Speh, T. W. (2002). Identifying Antecedents of Information Exchange within Supply Chains. International Journal of Physical Distribution and Logistics Management, 32, 755-770.

https://doi.org/10.1108/09600030210452431

Nazifa, T. H., \& Ramachandran, K. K. (2019). Information Sharing in Supply Chain Management: A Case Study between the Cooperative Partners in Manufacturing Industry. Journal of System and Management Sciences, 9, 19-47.

Pallant, J. (2020). SPSS Survival Manual: A Step by Step Guide to Data Analysis Using IBM SPSS. London: McGraw-Hill, Open University Press. https://doi.org/10.4324/9781003117452

Pamulety, T. C., \& Pillai, V. M. (2011). Impact of Information Sharing in Supply Chain Performance. In K. Shah, V. R. Lakshmi Gorty, \& A. Phirke (Eds.), Technology Systems and Management (pp. 327-332). Berlin, Heidelberg: Springer. https://doi.org/10.1007/978-3-642-20209-4_47

Seggie, S. H., Kim, D., \& Cavusgil, S. T. (2006). Do Supply Chain IT Alignment and Supply Chain Interfirm System Integration Impact upon Brand Equity and Firm Performance? Journal of Business Research, 59, 887-895.

https://doi.org/10.1016/j.jbusres.2006.03.005

Simatupang, T. M., \& Sridharan, R. (2002). The Collaborative Supply Chain. The International Journal of Logistics Management, 13, 15-30. https://doi.org/10.1108/09574090210806333

Sundram, V. P. K., Bahrin, A. S., Abdul Munir, Z. B., \& Zolait, A. H. (2018). The Effect of Supply Chain Information Management and Information System Infrastructure. Journal of Enterprise Information Management, 31, 751-770. https://doi.org/10.1108/JEIM-06-2017-0084

Sundram, V. P. K., Chhetri, P., \& Bahrin, A. S. (2020). The Consequences of Information Technology, Information Sharing and Supply Chain Integration, towards Supply Chain Performance and Firm Performance. Journal of International Logistics and Trade, 18, 15-31. https://doi.org/10.24006/jilt.2020.18.1.015

Vickery, S. K., Jayaram, J., Droge, C., \& Calantone, R. (2003). The Effects of an Integrative Supply Chain Strategy on Customer Service and Financial Performance: An Analysis of Direct versus Indirect Relationships. Journal of Operations Management, 21, 523-539. https://doi.org/10.1016/j.jom.2003.02.002

Wilkinson, I. (1981). Power, Conflict, and Satisfaction in Distribution Channels-An Empirical Study. International Journal of Physical Distribution \& Materials Management, 11, 20-30. https://doi.org/10.1108/eb014513

Yamane, Y. (1967). Mathematical Formulae for Sample Size Determination. 